\title{
EFFECT OF CORTISOL TREATMENT ON HORMONAL RELATIONSHIPS IN CONGENITAL ADRENAL HYPERPLASIA
}

\author{
GEORGE E. BACON, MARTHA L. SPENCER AND ROBERT P. KELCH \\ Department of Pediatrics, University of Michigan, Ann Arbor, Michigan
}

(Received 16 March 1976; revised 19 July 1976; accepted 16 September 1976)

\begin{abstract}
SUMM A R Y
The temporal relationship between administration of cortisol and serum $17 a$ hydroxyprogesterone was investigated in five patients aged 9-19 years with congenital adrenal hyperplasia due to 21 -hydroxylase deficiency. There was marked variability in the $17 a$-hydroxyprogesterone response (determined hourly for $24 \mathrm{~h}$ ) of individual patients to administration of cortisol. Mean concentration was less than $0.030 \mu \mathrm{mol} / 1$ in one patient but $0.519 \mu \mathrm{mol} / 1$ in another. Levels were higher in all patients while off treatment, and were greatest in those with salt-losing adrenal hyperplasia. Growth hormone secretion was not suppressed by treatment with cortisol. Withdrawal of cortisol for 3 days resulted in a significant decrease in the mean serum $\mathrm{FSH} / \mathrm{LH}$ ratio and a rise in serum testosterone in all subjects. Episodic release of gonadotrophins persisted in the adolescent patients.
\end{abstract}

Abnormalities of growth occur in patients with congenital adrenal hyperplasia (CAH). Excessive glucocorticoid treatment causes stunting, whereas inadequate therapy results in a rapid increase in height. It is frequently difficult to determine the precise regimen which will suppress androgen secretion without inhibiting linear growth. Recommended doses of cortisol* vary from 15 to $40 \mathrm{mg} / \mathrm{m}^{2} /$ day (Laron \& Pertzelan, 1968; Rappaport et al., 1968).

In the present study the temporal relationship between oral administration of cortisol and the serum concentration of $17 a$-hydroxyprogesterone (17-OHP) was studied during a $24 \mathrm{~h}$ period to determine if the typical every 8 - $\mathrm{h}$ dosage schedule provides adequate adrenal suppression. Serum concentrations of growth hormone (GH), total corticoids, follicle stimulating hormone (FSH), luteinizing hormone ( $\mathrm{LH})$, and testosterone were also determined.

\section{MATERIALS AND METHODS}

Subjects were five patients, aged 9-19 years, with CAH due to 21-hydroxylase deficiency. Subjects 1 and 2 were non salt-losers (Table 1). Patients were admitted to the Clinical Research Unit for 3 days on two separate occasions, in random sequence, at least 1 month

\footnotetext{
* The following trivial names have been used : cortisol: $11 \beta, 17,21$-trihy droxy-4-pregnane-3,20-dione; 21 -

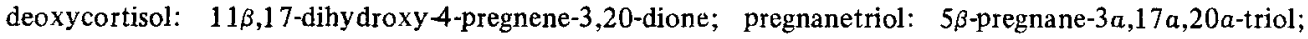
progesterone: 4-pregnene-3,20-dione; $17 a-\mathrm{OH}$ progesterone: $17 a$-hydroxy-4-pregnene-3,20-dione; testosterone: $17 \beta$-hydroxy-4-androsten-3-one.

Correspondence: Dr George E. Bacon, Department of Pediatrics, University of Michigan, Ann Arbor, Michigan, U.S.A.
} 
apart. During one hospitalization, treatment with cortisol was continued as usual. Dose ranged from 19 to $24 \mathrm{mg} / \mathrm{m}^{2} /$ day, similar to the $25 \mathrm{mg} / \mathrm{m}^{2} /$ day recommended by Brook et al. (1974). Approximateiy one quarter of the daily amount was given at 08.00 hours, a quarter at 16.00 hours and a half at 24.00 hours. In the other hospitalization, cortisol was withdrawn 1 day prior to admission. Patients requiring mineralocorticoid continued to receive $9 a$-fluoro-hydrocortisone during both admissions.

The study protocol was approved by the Committee to Review Grants for Clinical Research and Investigation Involving Human Beings, University of Michigan Medical Center. 'Informed Consent' forms were signed by each patient and parent with full knowledge of the procedure.

Table 1. Clinical data, serum 17a-hydroxyprogesterone, and growth hormone

\begin{tabular}{|c|c|c|c|c|c|c|c|c|}
\hline \multirow[b]{2}{*}{ Patient } & \multirow[b]{2}{*}{ Sex } & \multirow[b]{2}{*}{$\mathrm{CA} / \mathrm{BA}$} & \multicolumn{2}{|c|}{ Cortisol dose } & & \multirow{2}{*}{$\begin{array}{r}17-\mathrm{OHP} * \\
(\mu \mathrm{mol} / 1)\end{array}$} & \multicolumn{2}{|c|}{ Grow th hormone } \\
\hline & & & $\mathrm{mg} /$ day & $\mathrm{mg} / \mathrm{m}^{2} /$ day & & & $\mu \mathrm{g} / 1$ & $\begin{array}{c}\text { "Area" } \\
\mu \mathrm{g}-\mathrm{h} \times 10^{-3}\end{array}$ \\
\hline 1 & M & $8.9 / 12.5$ & $\begin{array}{c}25 \\
(5-5-15) \dagger\end{array}$ & 20 & $\begin{array}{l}\mathrm{Rx} \\
\text { No } \mathrm{Rx}\end{array}$ & $\begin{array}{l}0.036 \pm 0.006 \\
0.097 \pm 0.017\end{array}$ & $\begin{array}{l}1.3 \pm 0.3 \\
1.1 \pm 0.4\end{array}$ & $\begin{array}{l}27.8 \\
22.8\end{array}$ \\
\hline 2 & $\mathrm{~F}$ & $12.0 / 11.0$ & $\begin{array}{c}25 \\
(5-5-15)\end{array}$ & 19 & $\begin{array}{l}\mathrm{Rx} \\
\text { No } \mathrm{Rx}\end{array}$ & $\begin{array}{l}<0.030 \\
0.201 \pm 0.014\end{array}$ & $\begin{array}{l}3.3 \pm 0.9 \\
3.0 \pm 0.5\end{array}$ & $\begin{array}{l}78.5 \\
77.9\end{array}$ \\
\hline 3 & $\mathrm{~F}$ & $13.8 / 15.0$ & $\begin{array}{c}30 \\
(7.5-7.5-15)\end{array}$ & 19 & $\begin{array}{l}\text { Rx } \\
\text { No } R x\end{array}$ & $\begin{array}{l}0.061 \pm 0.008 \\
0.450 \pm 0.030\end{array}$ & $\begin{array}{l}2.8 \pm 0.6 \\
2.0 \pm 0.4\end{array}$ & $\begin{array}{l}59.4 \\
43.0\end{array}$ \\
\hline 4 & $\mathrm{~F}$ & 14.3/adult & $\begin{array}{c}30 \\
(7.5-7.5-15)\end{array}$ & 21 & $\begin{array}{l}\text { Rx } \\
\text { No } R x\end{array}$ & $\begin{array}{l}0.099 \pm 0.008 \\
0.381 \pm 0.022\end{array}$ & $\begin{array}{l}1.7 \pm 0.4 \\
0.9 \pm 0.2\end{array}$ & $\begin{array}{l}37.1 \\
22.1\end{array}$ \\
\hline 5 & $\mathrm{~F}$ & 18.8/adult & $\begin{array}{c}35 \\
(10-10-15)\end{array}$ & 24 & $\begin{array}{l}\mathrm{Rx} \\
\text { No } \mathrm{Rx}\end{array}$ & $\begin{array}{l}0.519 \pm 0.044 \\
0.949 \pm 0.055\end{array}$ & $\begin{array}{l}4.2 \pm 0.5 \\
2.0 \pm 0.2\end{array}$ & $\begin{array}{r}100.0 \\
46.0\end{array}$ \\
\hline
\end{tabular}

$\mathrm{CA}=$ Chronologic age (in years). $\mathrm{BA}=$ Bone age.

* Mean value \pm SE for $24 \mathrm{~h}$. Mean serum 17-OHP concentration in control group $<0.030 \mu$ mol/1. Mean 17-OHP for patients 1 and 2 (non-salt-losers) $=0.149 \pm 0.086$ (SD) $v .0 .599 \pm 0.257 \mu \mathrm{mol} / 1(P<0.01)$ for patients 3-5 (salt-losers) while off treatment.

$\dagger()=$ amount of individual doses.

Serum samples for 17-OHP and total corticosteroids were obtained hourly for $24 \mathrm{~h}$ during the third day of each admission. Samples for GH were obtained every hour from 08.00 to 15.00 hours and at $30 \mathrm{~min}$ intervals from 15.00 to 08.00 hours. Serum FSH and LH were determined every 20 min between 08.00 and 15.00 hours and hourly from 24.00 until 08.00 hours. Serum testosterone was measured at 08.00 hours on the day of the study. Urinary $24 \mathrm{~h}$ excretion of 17-oxosteroids (17-OS), 17-hydroxycorticosteroids (17.OHCS) and creatinine were determined for three consecutive days during both hospitalizations.

Serum samples for determination of 17-OHP were prepared by a modification of the methods of Franks (1974) and Pham-Huu-Trung et al. (1973). Serum (0.2 ml) was extracted with $2.0 \mathrm{ml}$ of chloroform:carbon tetrachloride $(1: 2)$ and $5 \mathrm{ml}$ of water. $1 \mathrm{ml}$ of the organic layer was dried, taken up three times in $0.1 \mathrm{ml}$ of dichloromethane, and applied to a $1 \mathrm{X}$ $15 \mathrm{~cm}$ column (with $100 \mathrm{ml}$ reservoir) containing $2.15 \mathrm{~g}$ of Sephadex LH20 in dichloromethane. The column was eluted with $100 \mathrm{ml}$ of dichloromethane. Correction for recovery $(\sim 85 \%)$ was determined for each assay. The $5-15 \mathrm{ml}$ fraction was dried and dissolved in 
$2.0 \mathrm{ml}$ of ethanol. Aliquots of $5,10,25$ and $50 \mu 1$, in duplicate, were found to be appropriate for assay.

The samples were quantitated by radioimmunoassay essentially as described by Abraham et al. (1971a). The antiserum, obtained from Dr Abraham, was prepared by immunizing a ewe with 11-deoxycortisol-21-monosuccinate-human serum albumin. Data regarding specificity have been published previously (Abraham et al., 1971b). In our laboratory, no interference from 21-deoxycortisol occurred. The antiserum reacted with progesterone, but some of this hormone was removed by the purification steps. Progesterone carried through the assay caused an effect equivalent to about $50 \%$ that of an equal amount of $17-0 H P$. Cortisol was removed by the purification steps. Intra-assay coefficients of variation averaged $7.1 \%$ for a low control serum and $11.0 \%$ for a high control serum.

Sixteen children, aged 6-19 years, without known adrenal pathology, had a mean 17 . OHP concentration of less than $0.030 \mu \mathrm{mol} / \mathrm{l}$. The method used would not be adequate for the study of unaffected subjects, since average values in normal prepubertal children are less than $0.002 \mu \mathrm{mol} / 1$ (Lippe et al., 1974). However, it was satisfactory for evaluation of patients with $\mathrm{CAH}$. In the present study, all subjects had mean 17-OHP concentrations greater than $0.030 \mu \mathrm{mol} / 1$, with the exception of patient 2 during the treatment period. The assay could be improved by increasing the size of the serum sample, but limitations on withdrawal of blood precluded this possibility.

Total corticosteroids were measured by Murphy's (1967) method using an antiserum rather than cortisol binding globulin. Serum GH was determined by double antibody radioimmunoassay (Youlton et al., 1969).

Serum FSH and LH were measured by radioimmunoassays (Lee et al., 1970; Midgley, 1966,1967 ; Midgley \& Jaffe, 1971). The mean intra-assay coefficients of variation at $20 \%$ and $80 \%$ inhibition were $5.2 \% \pm 0.2$ (SE) and $10.4 \% \pm 0.3$ (SE) for the FSH assay $(n=24)$, and $5.5 \% \pm 0.3(\mathrm{SE})$ and $11.0 \% \pm 0.6(\mathrm{SE})$ for the LH assay $(n=20)$. The sensitivities of the gonadotrophin assays, determined as the amount of 2nd-IRP-HMG in miu/tube predicted to give the mean activity associated with the buffer control tube, less two standard deviations, averaged $0.27 \mathrm{miu} \pm 0.03$ (SE) for FSH and $0.20 \mathrm{miu} \pm 0.04$ (SE) for LH. Duplicate $200 \mu \mathrm{l}$ (FSH) or $100 \mu \mathrm{l}(\mathrm{LH})$ samples were used.

Serum testosterone was measured by a modification of the method of Ismail et al. (1972). Ammonium sulphate precipitation was replaced by extraction with benzene:hexane $(1: 2)$. An antiserum raised in rabbits against testosterone-11-hemisuccinate conjugated to bovine serum albumin, and testosterone-11-hemisuccinate- $\left[{ }^{125} \mathrm{I}\right]$ tyrosine-methyl ester were used as the first antibody and radiolabeled ligand respectively. Assay sensitivity was $10 \mathrm{pg} /$ tube. Gonadotrophin and testosterone calculations were performed by the computer program described by Duddleson et al. (1972).

Urinary 17-OS and 17-OHCS were determined by standard methods (Zimmerman, 1955; Silber \& Porter, 1954).

The data were analysed by Student's unpaired ' $t$ ' test. Areas under the GH curves were determined by triangulation.

\section{RESULTS}

\section{7a-Hydroxyprogesterone and total corticosteroids}

Serum 17-OHP and total corticoid concentrations for each patient are presented in Figs. $1-5$. There was striking variability in the $17-\mathrm{OHP}$ response of individual patients to adminis- 
tration of cortisol (Table 1). Mean 17-OHP level was less than $0.030 \mu \mathrm{mol} / 1$ in patient 2 during treatment, but $0.519 \mu \mathrm{mol} / 1$ in patient 5 . In subject 5 (Fig. 5), and possibly in subject 4 (Fig. 4), the results suggested a reciprocal relationship between total corticoid and 17-0HP levels.

Concentrations of 17-OHP were higher in all patients while off treatment, and were greatest in those with salt losing $\mathrm{CAH}$. A circadian variation was observed in each case.

The increased corticoid concentrations obtained following oral administration of cortisol provided evidence that the drug was ingested and absorbed.

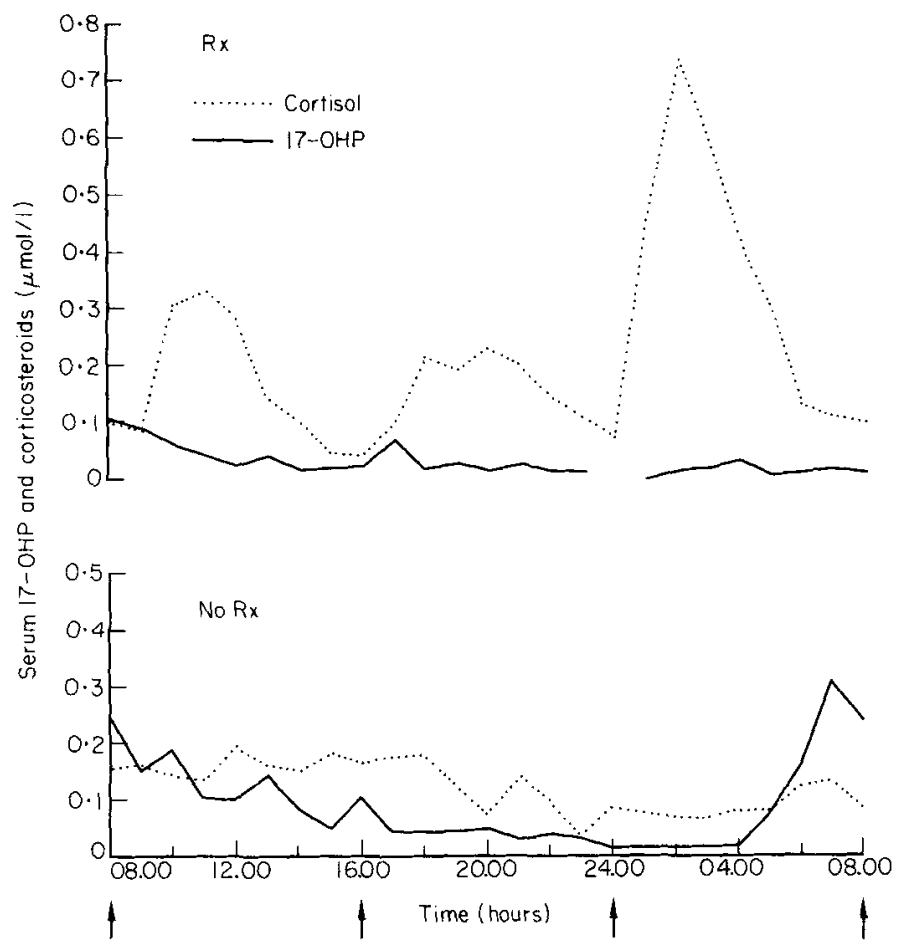

Fig. 1. Patient 1, male, 8 years 11 months.

Figs. 1-5. Serum 17-OHP and corticosteroid (cortisol) concentrations in five patients during cortisol therapy (upper panel), and after treatment had been discontinued for 3 days (lower panel). Arrows denote times of cortisol administration during treatment study.

Growth hormone. GH concentrations are depicted in Table 1 and Fig. 6. Treatment and non-treatment patterns were remarkably similar in all patients. Increased daytime values during treatment in patient 5 may have been secondary to difficulties in maintaining a patent intravenous cannula. There was no evidence to suggest that cortisol suppressed GH secretion. Indeed, mean GH concentrations and areas under the GH secretory curves were slightly greater in all patients during treatment.

FSH and $L H$. Serum FSH patterns are illustrated in Table 2 and Fig. 7. In general, FSH concentrations fluctuated minimally. Mean FSH values were significantly greater $(P<0.025)$ during the treatment study in all but one patient (No. 3); the differences were more apparent during the daytime sampling period. Patients 1,2 and 5 failed to show consistent 

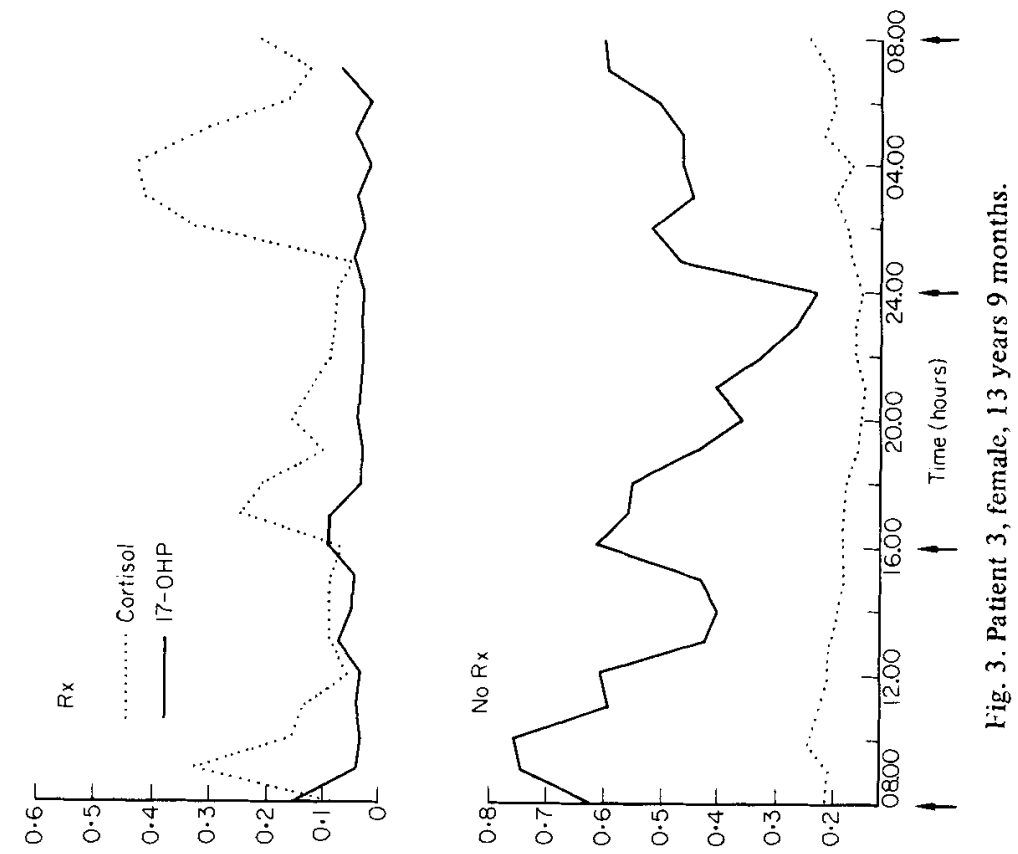

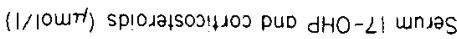

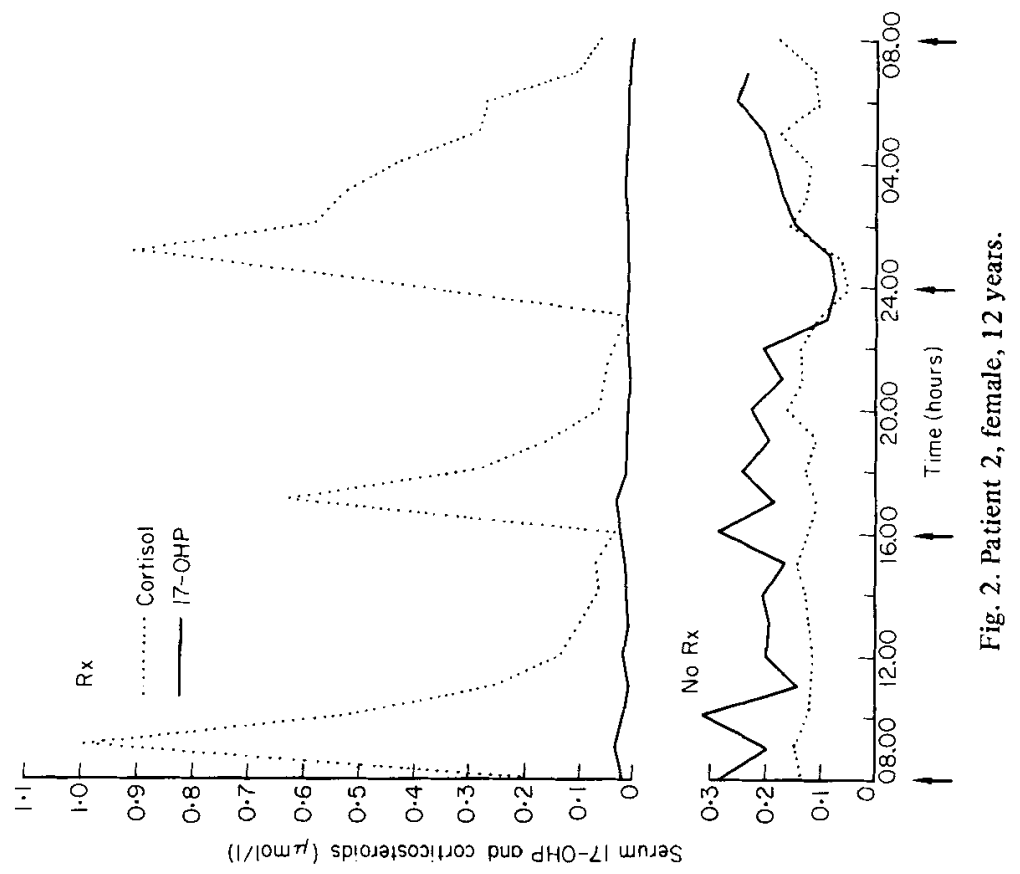



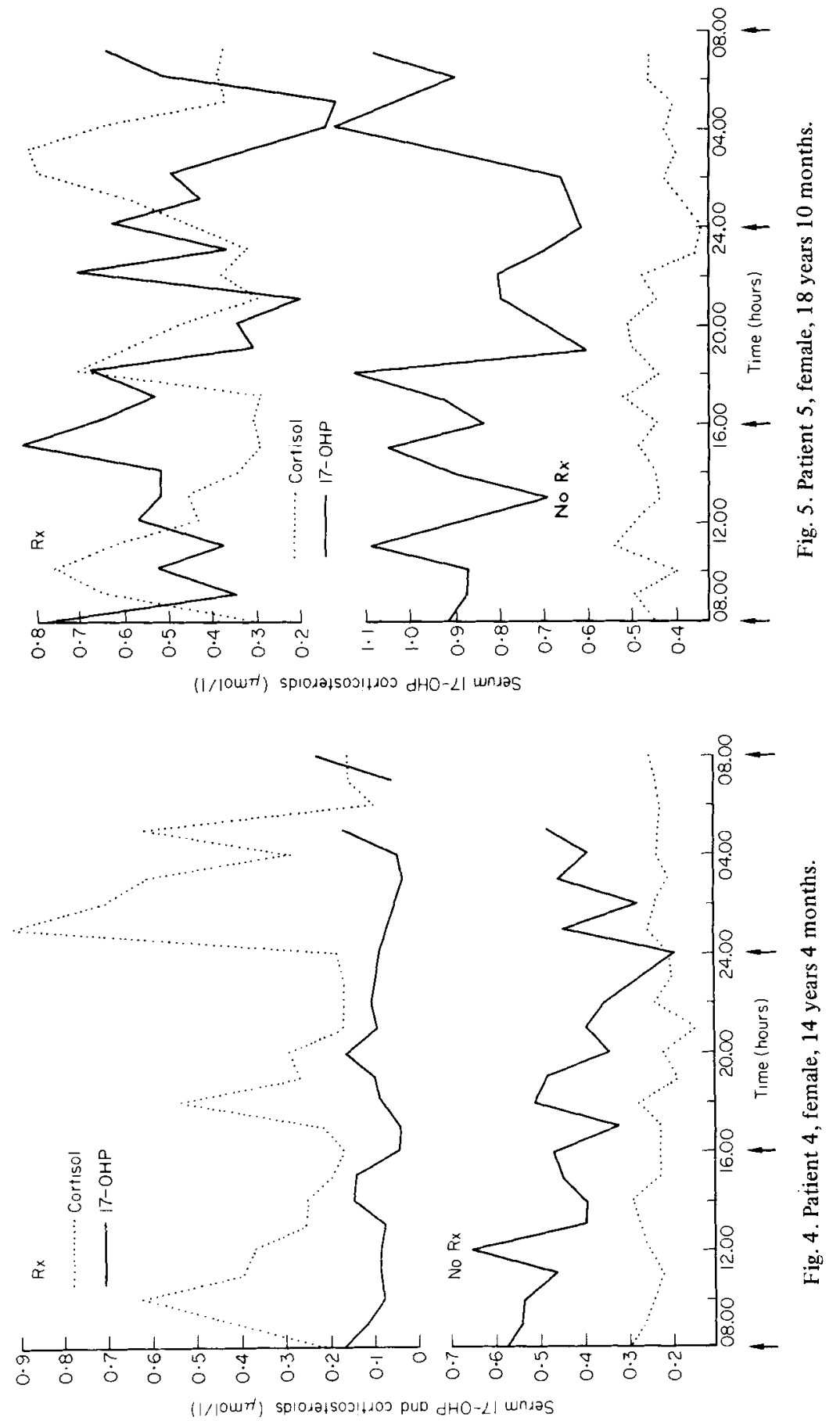
differences between nocturnal and daytime FSH concentrations. Mean nocturnal FSH concentrations of patients 3 and 4 were significantly greater $(P<0.025)$ than daytime values during both studies.

Serum LH patterns are shown in Table 2 and Figs. 8 and 9. LH concentrations were relatively constant throughout the day in the two youngest patients. In the three oldest

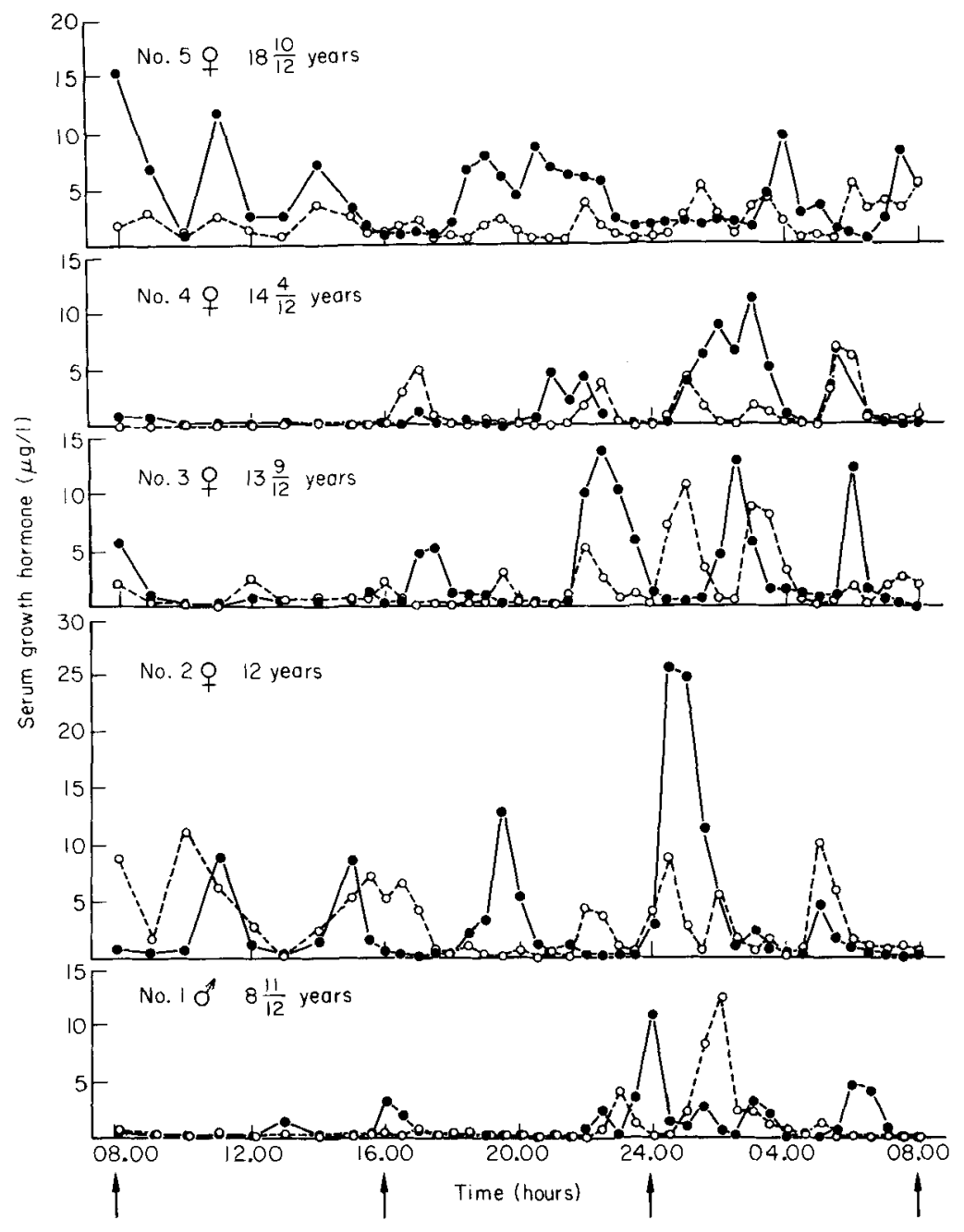

Fig. 6. Serum GH concentrations in five patients with CAH during cortisol therapy (•) and after treatment had been discontinued for 3 days $(0)$. Arrows denote times of cortisol administration during treatment study.

patients, LH was secreted episodically during both studies (Midgley \& Jaffe, 1971); however, the amplitudes of the secretory bursts wère greater after cortisol had been withdrawn for 3 days. In contrast to the minor changes in FSH, mean serum LH was significantly greater $(P<0.01)$ after cortisol withdrawal in all patients except No. 2. Mean nocturnal LH values were consistently greater than daytime values in patients 4 and $5(P<0.05)$. Analysis of the 


\begin{tabular}{|c|c|c|c|c|c|c|}
\hline \multicolumn{2}{|c|}{ Patient } & $\begin{array}{l}\mathrm{FSH}^{*} \\
(\mathrm{iu} / \mathrm{l})\end{array}$ & $\begin{array}{l}\mathrm{LH}^{*} \\
(\mathrm{iu} / \mathrm{l})\end{array}$ & $\mathrm{FSH} / \mathrm{LH}^{*}$ & $\begin{array}{l}\text { Testosterone } \dagger \\
\text { (nmol/l) }\end{array}$ & $\begin{array}{c}17-\mathrm{OS} \ddagger \\
(\mu \mathrm{mol} / \mathrm{day})\end{array}$ \\
\hline 1 & $\begin{array}{l}\text { Treatment } \\
\text { No treatment }\end{array}$ & $\begin{array}{l}3.2 \pm 0.14 \\
2.7 \pm 0.13\end{array}$ & $\begin{array}{l}3.6 \pm 0.2 \\
4.5 \pm 0.2\end{array}$ & $\begin{array}{l}0.97 \pm 0.06 \\
0.61 \pm 0.04\end{array}$ & $\begin{array}{l}10.4 \\
24.3\end{array}$ & $\begin{array}{l}22.5 \\
27.4\end{array}$ \\
\hline 2 & $\begin{array}{l}\text { Treatment } \\
\text { No treatment }\end{array}$ & $\begin{array}{l}6.5 \pm 0.6 \\
5.2 \pm 0.3\end{array}$ & $\begin{array}{l}3.1 \pm 0.2 \\
3.3 \pm 0.1\end{array}$ & $\begin{array}{l}2.42 \pm 0.4 \\
1.66 \pm 0.1\end{array}$ & $\begin{array}{r}3.5 \\
10.4\end{array}$ & $\begin{array}{l}13.2 \\
39.5\end{array}$ \\
\hline 3 & $\begin{array}{l}\text { Treatment } \\
\text { No treatment }\end{array}$ & $\begin{array}{l}7.6 \pm 0.2 \\
7.9 \pm 0.4\end{array}$ & $\begin{array}{l}13.4 \pm 0.7 \\
22.2 \pm 1.6\end{array}$ & $\begin{array}{l}0.61 \pm 0.03 \\
0.39 \pm 0.02\end{array}$ & $\begin{array}{l}13.9 \\
48.5\end{array}$ & $\begin{array}{r}39.2 \\
130.0\end{array}$ \\
\hline 4 & $\begin{array}{l}\text { Treatment } \\
\text { No treatment }\end{array}$ & $\begin{array}{l}13.3 \pm 0.6 \\
10.6 \pm 0.9\end{array}$ & $\begin{array}{r}9.7 \pm 0.7 \\
15.0 \pm 1.4\end{array}$ & $\begin{array}{l}1.15 \pm 0.09 \\
0.75 \pm 0.04\end{array}$ & $\begin{array}{l}48.5 \\
86.7\end{array}$ & $\begin{array}{r}69.3 \\
129.7\end{array}$ \\
\hline 5 & $\begin{array}{l}\text { Treatment } \\
\text { No treatment }\end{array}$ & $\begin{array}{l}7.6 \pm 0.3 \\
6.1 \pm 0.2\end{array}$ & $\begin{array}{l}16.8 \pm 1.2 \\
26.8 \pm 1.5\end{array}$ & $\begin{array}{l}0.50 \pm 0.03 \\
0.25 \pm 0.02\end{array}$ & $\begin{array}{l}58.9 \\
72.8\end{array}$ & $\begin{array}{r}54.8 \\
210.8\end{array}$ \\
\hline
\end{tabular}

* Mean \pm SE.

$\dagger 08.00$ hours sample. Normal values: prepubertal children $<7.0 \mathrm{nmol} / \mathrm{l}$, premenopausal women $3.5-$ $40.0 \mathrm{nmol} / 1$.

$\ddagger$ Study day only.

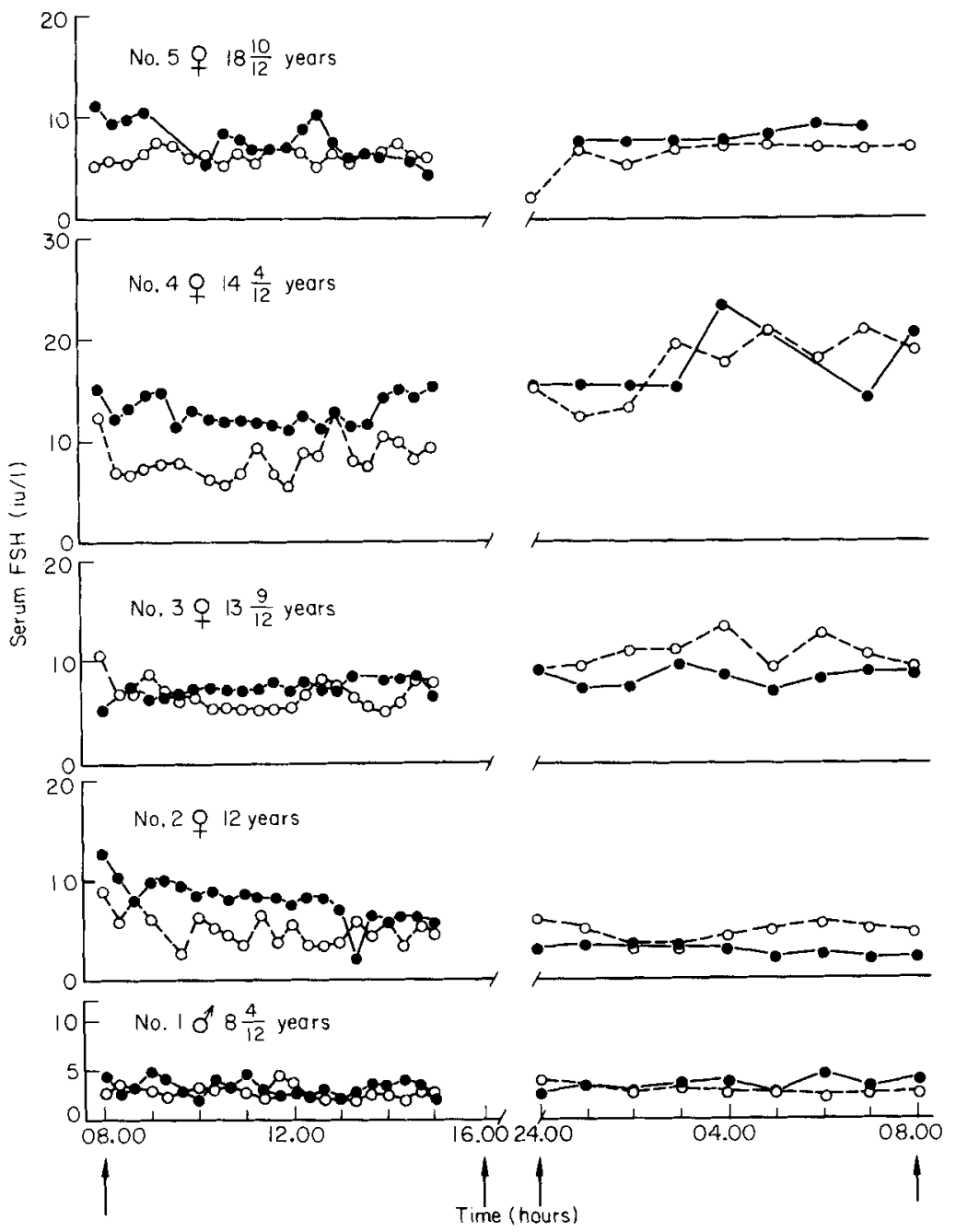

Fig. 7. Serum FSH concentrations in five patients with CAH during cortisol therapy $(\bullet)$ and after treatment had been discontinued for 3 days $(0)$. Arrows denote times of cortisol administration during treatment study. 

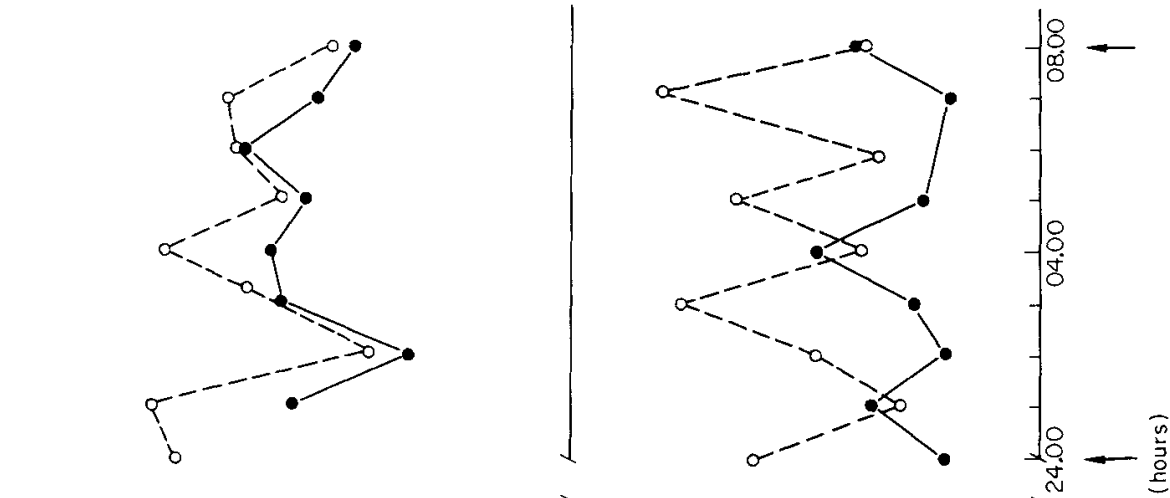

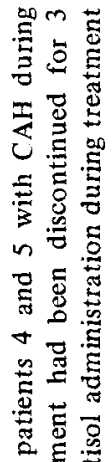

$\therefore$ 焉

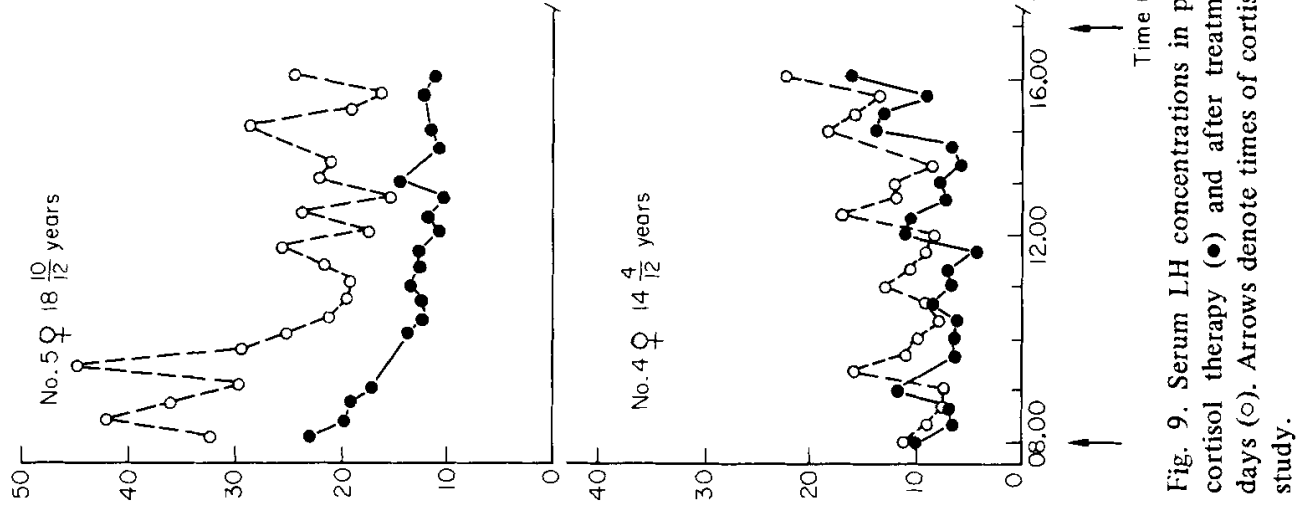

(1/nI) Hᄀ Undas

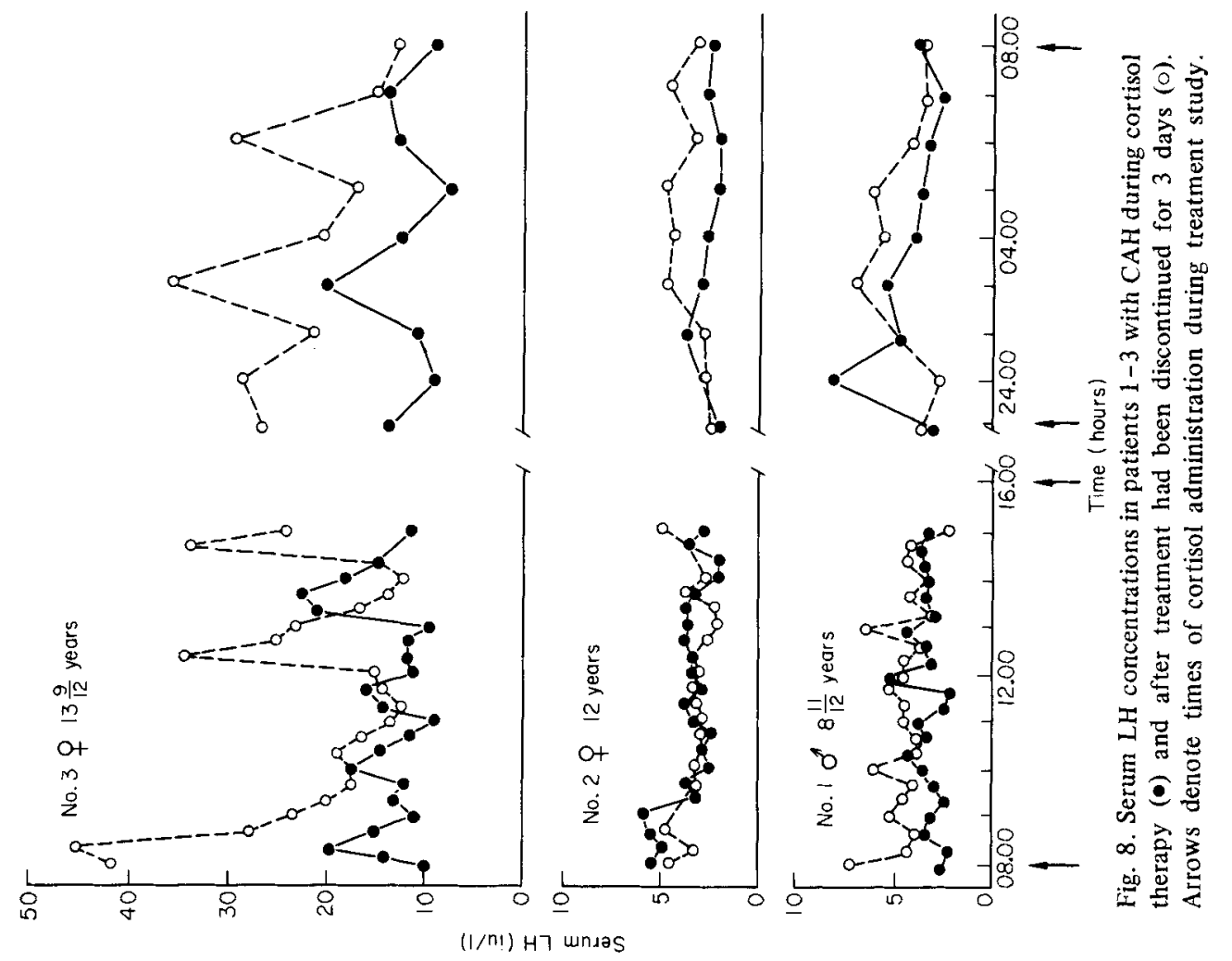


FSH/LH ratio of all serum samples revealed a significantly lower $(P<0.05)$ mean value during the non-treatment study in all patients.

Testosterone. Serum testosterone concentrations were lower in all patients while on treatment (Table 2), but the difference was not significant and only two subjects (Nos. 2 and 3) had values in the normal range for their age and sex.

Urinary 17-oxosteroids and 17-hydroxysteroids. During the non-treatment period, daily 17-OS values tended to increase progressively through the fourth day after withdrawal of cortisol. Treatment with cortisol caused variable suppression of 17-OS (Table 2) but resulted in a significant decrease $(P<0.025)$ for the group. Considerable day-to-day fluctuation occurred in two subjects. Values ranged from 54.8 to $102.6 \mu \mathrm{mol} /$ day in patient 5 even though the dose of cortisol was constant for the 3 day period.

Urinary 17-OHCS excretion was relatively low $\left(\bar{x}=3.9 \mu \mathrm{mol} / \mathrm{m}^{2} /\right.$ day) for the five subjects during the non-treatment period and was higher in the non-salt-losers $(\bar{x}=5.8$ vs. $2.8 \mu \mathrm{mol} / \mathrm{m}^{2} /$ day, $\left.P<0.05\right)$. Mean excretion during therapy $\left(\bar{x}=20.4 \mu \mathrm{mol} / \mathrm{m}^{2}\right)$ was about twice the average normal value $\left(8.3 \mu \mathrm{mol} / \mathrm{m}^{2}\right)$, consistent with the fact that the administered dose of cortisol was roughly double the physiologic production rate of $33.1 \mu \mathrm{mol} / \mathrm{m}^{2}$ (Kenny et al., 1970).

\section{DISCUSSION}

Concentrations of 17-OHP varied considerably among untreated patients, but were almost always above the normal range for the method employed. The three subjects with salt-losing $\mathrm{CAH}$ had the highest values, consistent with the hypothesis that the metabolic block is more severe in this form of the disease (Bongiovanni \& Eberlein, 1958). All patients demonstrated a diurnal variation.

Patient 5, a 19-year-old girl with salt-losing $\mathrm{CAH}$, demonstrated the poorest control. Her mineralocorticoid had been successfully withdrawn during adolescence, and therefore was not administered during the study. Hughes \& Winter (1976) have recently noted that even slightly inadequate mineralocorticoid therapy, manifested by elevated plasma renin activity with normal electrolytes, may cause increased 17-OHP despite appropriate cortisol replacement. These authors also reported normal 17.0HP levels in eight of eleven children treated with at least $20 \mathrm{mg} / \mathrm{m}^{2} /$ day of cortisol. In the others, $17-0 H P$ concentrations were elevated to varying degrees. Control was improved by increasing the dose (in one patient) or simply modifying the administration schedule.

In earlier studies, Lippe et al. (1974) obtained serial 17-OHP determinations for approximately 3 days in two subjects. Periodic administration of oral cortisone resulted in continuous adrenal suppression in one well-controlled patient. In the other subject, 17-OHP concentrations were elevated prior to treatment, but a substantial decrease was noted following oral cortisone. Atherden et al. (1972) also determined serial 17-OHP concentrations in three children with CAH. A marked circadian variation was observed in the two untreated patients. One subject, who was treated with cortisone acetate every $6 \mathrm{~h}$, likewise demonstrated considerable variation, with peak 17-OHP levels of about $0.300 \mu \mathrm{mol} / \mathrm{l}$.

Patients with $\mathrm{CAH}$ often receive oral cortisol three times daily or every $8 \mathrm{~h}$. The results of the present study suggest that more frequent administration may be required for adequate suppression of serum 17.OHP in some patients, even when the total daily dose approximates double the normal physiologic production rate. Possibly, the use of a delayed-release prep- 
aration of cortisol, or of a synthetic substitute with a longer half-life, would provide better control with less steroid. However, it has been reported that growth suppression is greater with some of the steroid analogs than with the naturally occurring hormone (Laron \& Pertzelan, 1968), a potential disadvantage in patients who have not reached their final height. Recently, McKenna et al. (1976) have suggested that suppression of precursor steroids to normal necessarily requires supraphysiologic amounts of cortisol; the alternative is to permit a mild excess of precursor steroid secretion, with resultant elevation of urinary 17-OS and pregnanetriol.

Serial 17-OHP determinations were helpful in assessing the degree of control of $\mathrm{CAH}$ during a $24 \mathrm{~h}$ period and in demonstrating the relationship to exogeneous cortisol but this procedure obviously is impractical for routine use. Because of the frequent changes in concentration, the usefulness of a single random determination of 17-0HP in prediciting the status of a treated patient has been questioned (Lippe et al., 1974). However, Hughes \& Winter (1976) found good agreement between the $08.00,12.00,18.00$ or 24.00 hours serum 17-OHP concentration and urinary pregnanetriol excretion in the great majority of cases. In one of our patients (No. 2), 17-OS excretion and the first 17-OHP measurement obtained at 08.00 hours were normal. In the others, both values were elevated. Concordance was noted in all but one subject using the 17-OHP concentration obtained at either 09.00 hours, or at 08.00 hours at the conclusion of the study day. Therefore, serum 17-OHP measurements obtained at specified times would appear to be reasonably reliable for monitoring therapy. In addition, 17-OHP determinations have proven useful in the diagnosis of CAH (Barnes \& Atherden, 1972; Franks, 1974; Youssefnajadian \& David, 1975).

The total corticosteroid concentrations were relatively high in patient 5 during the nontreatment period $(\bar{x}=0.455 \mu \mathrm{mol} / \mathrm{l})$. This was probably due to interference from cortisol precursors, primarily 21-deoxycortisol, since urinary 17-OHCS excretion on the day was only $4.1 \mu \mathrm{mol}$. On the other hand, Fukushima et al. (1975) have demonstrated normal cortisol production rates (CPR) in CAH. They postulated that patients with severe enzyme deficiency synthesize adequate amounts of cortisol by increasing adrenocorticotrophic hormone secretion. The CPR in one of their subjects was in the high normal range.

Our data suggest that GH secretion in children with $\mathrm{CAH}$ is adequate and that the nocturnal release is not suppressed by treatment with cortisol. Vasquez et al. (1972) made a similar observation in a 14-year-old girl. Therefore, the impaired linear growth sometimes observed in these patients probably is not a result of abnormal GH secretion.

Finkelstein et al. (1973) reported that untreated patients with CAH secreted more GH than normal prepubertal children of comparable age, and suggested that the rapid growth of these subjects might be related to increased $\mathrm{GH}$. The $\mathrm{GH}$ concentrations of the untreated patients reported here did not appear to be elevated, but concurrent measurements in unaffected children were not performed.

In the current study, withdrawal of glucocorticoid therapy for 3 days significantly altered the serum concentrations and secretory patterns of gonadotrophins in the two prepubertal (Nos. 1 and 2) and three pubertal (Nos. 3-5) children with CAH. As illustrated by the changes in 17-OS excretion, serum 17-OHP and testosterone concentrations, adrenal sex steroid secretion rose during the non-treatment study. Glucocorticoid withdrawal, however, significantly decreased the FSH/LH ratio in all patients. This change contrasts sharply with the expected negative feedback effects of sex steroids on gonadotrophin secretion and with the minimal effects of adrenal suppression with dexamethasone on serum gonadotrophins in adult subjects (Faiman \& Winter, 1971; Kim et al., 1974). The mechanism(s) of the differen- 
tial modulation of FSH and LH secretion by increased concentrations of adrenal sex steroids is not readily apparent.

Boyar et al. (1973) studied two untreated boys with CAH and advanced skeletal maturation. In both patients there was episodic secretion of gonadotrophins with increased LH release during sleep. These authors postulated that prolonged secretion of increased amounts of adrenal steroids may stimulate the maturation of the hypothalamic-pituitary-gonadal axis. The 90-120 min periodicity of LH bursts found in our three oldest patients is similar to reported data in normal adults, pubertal children, and hypogonadal patients (Johnson, 1974; Kelch et al., 1973; Midgley \& Jaffe, 1971; Nankin \& Troen, 1971). The nocturnal rise in gonadotrophin concentrations in these patients resembles the patterns reported in early to mid-pubertal children (Boyar et al., 1972). The current study therefore is in agreement with the findings of Boyar et al.(1973) and lends support to their speculation. On the other hand, Wentz et al. (1976) have recently reported a blunted peak LH response to gonadotrophinreleasing hormone in two pubertal females with poorly controlled CAH. Thus, although we demonstrated a decreased FSH/LH ratio following short-term withdrawal of cortisol, lack of treatment for a longer period may have resulted in the expected suppression of serum gonadotrophins.

The altered gonadotrophin secretory patterns noted in our patients after relatively brief withdrawal of glucocorticoid therapy could conceivably explain, in part, the high incidence of amenorrhoea and irregular menses in females with $\mathrm{CAH}$. Follicular development and subsequent ovulation might be impaired by the decreased FSH/LH ratio. Similarly, decreased FSH/LH ratios have been reported by Yen et al. (1974) in selected patients with polycystic ovarian disease, another condition often associated with increased adrenal sex steroid secretion. This study suggests the need for continuous, good control of adrenal steroid production in $\mathrm{CAH}$ to allow the development of regular menstrual cycles.

\section{ACKNOWLEDGMENTS}

We gratefully acknowledge the technical assistance of M. Hepburn, K. Kersey, M. Markovs, J. Huss and B. Needham, and the secretarial assistance of F. Rupp. This work was supported in part by National Foundation Grant 340633, and USPHS Grants GM 15559 and HD08333.

\section{REFERENCES}

ABRAHAM, G.E., SWERDLOFF, R.S., TULCHINSKY, D., HOPPER, K. \& ODELL, W.C. (1971a) Radioimmunoassay of plasma hydroxyprogesterone. Journal of Clinical Endocrinology and Metabolism, 33, 42-46.

ABRAHAM, G.E., SWERDLOFF, R., TULCHINSKY, D. \& ODELL, W.D. (1971b) Radioimmunoassay of plasma progesterone. Journal of Clinical Endocrinology and Metabolism, 32, 619-624.

ATHERDEN, S.H., BARNES, N.D. \& GRANT, D.B. (1972) Circadian variation in plasma 17 -hydroxyprogesterone in patients with congenital adrenal hyperplasia. Archives of Disease in Childhood, 47, $602-604$.

BARNES, N.D. \& ATHERDEN, S.H. (1972) Diagnosis of congenital adrenal hyperplasia by measurement of plasma 17-hydroxyprogesterone. Archives of Disease in Childhood, 47, 62-65.

BONGIOVANNI, A.M. \& EBERLEIN, W.R. (1958) Defective steroidal biogenesis in congenital adrenal hyperplasia. Pediatrics, 21, 661-672.

BOYAR, R., FINKELSTEIN, J., ROFFWARG, H., KAPEN, S., WEITZMAN, E. \& HELLMAN, L. (1972) Synchronization of augmented luteinizing hormone secretion with sleep during puberty. New England Journal of Medicine, 287, 582-586. 
BOYAR, R., FINKELSTEIN, J.W., DAVID, R., ROFFWARG, H., KAPEN, S., WEITZMAN, E.D. \& HELLMAN, L. (1973) Twenty-four hour patterns of plasma luteinizing hormone and folliclestimulating hormone in sexual precocity. New England Journal of Medicine, 289, 282-286.

BROOK, C.G.D., JACHMANN, M., PRADER, A. \& MURSET, G. (1974) Experience with long-term therapy in congenital adrenal hyperplasia. Joumal of Pediatrics, 85, 12-19.

DUDDLESON, W.G., MIDGLEY, A.R., Jr \& NISWENDER, G.D. (1972) Computer program sequence for analysis and summary of radioimmunoassay data. Computers and Biochemical Research, 5, 205-217.

FAIMAN, C. \& WINTER, J.S.D. (1971) Diurnal cycles in plasma FSH, testosterone and cortisol in men. Journal of Clinical Endocrinology and Metabolism, 33, 186-192.

FINKELSTEIN, J.W., BOYAR, R.M., ROFFWARG, H.P., KREAM, J., FUKUSHIMA, D.K., GALLAGHER, T.F. \& HELLMAN, L. (1973) Growth hormone secretion in congenital adrenal hyperplasia. Journal of Clinical Endocrinology and Metabolism, 36, 121-124.

FRANKS, R.C. (1972) Screening tests for congenital adrenal hyperplasia. Journal of Clinical Endocrinology and Metabolism, 35, 831-835.

FRANKS, R.C. (1974) Plasma 17-hydroxyprogesterone, 21-deoxycortisol and cortisol in congenital adrenal hyperplasia. Journal of Clinical Endocrinology and Metabolism, 39, 1099-1102.

FUKUSHIMA, D.K., FINKELSTEIN, J.W., YOSHIDA, K., BOYAR, R.M. \& HELLMAN, L. (1975) Pituitary-adrenal activity in untreated congenital adrenal hyperplasia. Journal of Clinical Endo. crinology and Metabolism, 40, 1-12.

HUGHES, I.A. \& WINTER, J.S.D. (1976) The application of a serum $170 H$-progesterone radioimmunoassay to the diagnosis and management of congenital adrenal hyperplasia. Journal of Pediatrics, $\mathbf{8 8}$, $766-773$.

ISMAIL, A.A.A., NISWENDER, G.D. \& MIDGLEY, A.R., Jr (1972) Radioimmunoassay of testosterone without chromatography. Journal of Clinical Endocrinology and Metabolism, 34, 177-184.

JOHANSON, A. (1974) Fluctuations of gonadotrophin levels in children. Journal of Clinical Endocrinology and Metabolism, 39, 154-159.

KELCH, R.P., CONTE, F.A., KAPLAN, S.L. \& GRUMBACH, M.M. (1973) Episodic secretion of luteinizing hormone (LH) in adolescent patients with the syndrome of gonadal dysgenesis. Journal of Clinical Endocrinology and Metabolism, 36, 424-427.

KENNY, F.M., RICHARDS, C. \& TAYLOR, F.H. (1970) Reference standards for cortisol production and 17-hydroxy-corticosteroid excretion during growth: variation in the pattern of excretion of radiolabeled cortisol metabolites. Metabolism, 19, 280-290.

KIM, M.H., HOSSEINIAN, A.H. \& DUPON, C. (1974) Plasma levels of estrogens, androgens and progesterone during normal and dexamethasone-treated cycles. Journal of Clinical Endocrinology and Metabolism, 39, 706-712.

LARON, Z. \& PERTZELAN, A. (1968) The comparative effect of $6 a$-fluoroprednisolone, $6 a$-methylprednisolone, and hydrocortisone on linear growth of children with congenital adrenal virilism and Addison's disease. Journal of Pediatrics, 73, 774-782.

LEE, P.A., MIDGLEY, A.R., Jr \& JAFFE, R.B. (1970) Regulation of human gonadotrophins. VI. Serum follicle stimulating and luteinizing hormone determinations in children. Journal of Clinical Endo. crinology and Metabolism, 31, 248-253.

LIPPE, B.M., LaFRANCHI, S.H., LAVIN, N., PARLOW, A., CYOUTUPA, J. \& KAPLAN, S.A. (1974) Serum 17-a-hydroxyprogesterone, progesterone, estradiol, and testosterone in the diagnosis and management of congenital adrenal hyperplasia. Journal of Pediatrics, 85, 782-787.

McKENNA, T.J., JENNINGS, A.S., LIDDLE, G.W. \& BURR, I.M. (1976) Pregnenolone, 17-OHpregnenolone, and testosterone in plasma of patients with congenital adrenal hyperplasia. Journal of Clinical Endocrinology and Metabolism, 42, 918-925.

MIDGLEY, A.R., Jr (1966) Radioimmunoassay: a method for human chorionic gonadotrophin and human luteinizing hormone. Endocrinology', 79, 10-18.

MIDGLEY, A.R., Jr (1967) Radioimmunoassay for human follicle-stimulating hormone. Journal of Clinical Endocrinology and Metabolism, 27, 295-299.

MIDGLEY, A.R., Jr \& JAFFE, R.B. (1971) Regulation of human gonadotropins. I. Episodic flutuation of LH during the menstrual cycle. Journal of Clinical Endocrinology and Metabolism, 33, 962-969.

MURPHY, B.E.P. (1967) Some studies of the protein-binding of steroids and their application to the routine micro and ultramicro measurement of various steroids in body fluids by competitive proteinbinding radioassay. Journal of Clinical Endocrinology and Metabolism, 27, 973-990. 
NANKIN, H.R. \& TROEN, P. (1971) Repetitive luteinizing hormone elevations in serum of normal man. Journal of Clinical Endocrinology and Metabolism, 33, 558-560.

PHAM-HUU-TRUNG, M.T., GOUMELEN, M. \& GIRARD, F. (1973) The simultaneous assay of cortisol and $17 a$-hydroxyprogesterone in the plasma of patients with congenital adrenal hyperplasia. Acta Endocrinologica, 75, 316-330.

RAPPAPORT, R., CORNU, G. \& ROYER, P. (1968) Steroid growth in congenital adrenal hyperplasia treated with hydrocortisone. Journal of Pediatrics, 73, 760-766.

SILBER, R.H. \& PORTER, C.C. (1954) Determination of 17,21-dihydroxy-20-ketosteroids in urine and plasma. Journal of Biological Chemistry, 210, 923-932.

VAZQUEZ, A.M., SCHUTT-AINE, J.C., KENNY, F.M., RICHARDS, C. \& ANTHONY, D. (1972) Effect of cortisone therapy on the diurnal pattern of growth hormone secretion in congenital adrenal hyperplasia. Journal of Pediatrics, $80,433-440$.

WENTZ, A.C., GARCIA, S.C., KLINGENSMITH, G.J., MIGEON, C.J. \& JONES, S.G. (1976) Gonadotropin output and response to LRH administration in congenital virilizing adrenal hyperplasia. Joumal of Clinical Endocrinology and Metabolism, 42, 239-246.

YEN, S.S.C., VANDENBERG, G. \& SILER, T.M. (1974) Modulation of pituitary responsiveness to LRF by estrogen. Journal of Clinical Endocrinology and Metabolism, 39, 170-177.

YOULTON, R., KAPLAN, S.L. \& GRUMBACH, M.M. (1969) Growth and growth hormone. IV. Limitations of the growth hormone response to insulin and arginine and of the immunoreactive insulin response to arginine in the assessment of growth hormone deficiency in children. Pediatrics, 43, 989-1004.

YOUSSEFNEJADIAN, E. \& DAVID, R. (1975) Early diagnosis of congenital adrenal hyperplasia by measurement of 17-hydroxyprogesterone. Clinical Endocrinology, 4, 451-454.

ZIMMERMAN, W. (1955) Vergleich verschiedener modifikationen der m-dinitrobenzol-reaktion auf 17ketosteroide. Hoppe-Seyler's Zeitschrift fur Physiologische Chemie (Berlin), 300, 141-146. 